\title{
ULTRASOUND ASSISTED EXTRACTION OF APRICOT KERNEL OIL: EFFECT ON PHYSICOCHEMICAL, MORPHOLOGICAL CHARACTERISTICS, AND FATTY ACID COMPOSITION
}

\author{
B. GAYAS ${ }^{\mathrm{a} *}$, G. KAUR ${ }^{\mathrm{a}}$ and A. SINGH \\ ${ }^{a}$ Department of Processing and Food Engineering; ${ }^{\mathrm{b}}$ Department of Food Science and Technology, Punjab \\ Agricultural University, Ludhiana, Punjab, 141004. India
}

(Received: 28 March 2019; accepted: 19 August 2019)

\begin{abstract}
The application of ultrasound during extraction of oil from apricot kernels using hexane was evaluated and compared with conventional methods (mechanical extraction and Soxhlet extraction). Results show that ultrasound assisted extraction (UAE) yields more oil with less solvent consumption. The oil yield from UAE, SE, and ME were $44.72 \%$, $44.33 \%$, and $35.06 \%$, respectively. It is noteworthy that it took $44 \mathrm{~min}$ to extract oil by UAE method, while alike yield was obtained from SE in 6 hours. Oil extracted by UAE exhibited significantly higher peroxide and ester values. The functional groups of apricot kernel oil were analysed using Fourier transform infrared spectroscopy. Untreated and treated kernel powders were studied by scanning electron microscopy, and the development of microstructures and disruption of cell walls were evaluated. Our study suggests that ultrasound assisted extraction may be an effective method to extract edible oils by achieving higher efficiency in shorter extraction time.

Keywords: apricot kernel oil, ultrasound assisted extraction, FT-IR, SEM, fatty acid
\end{abstract}

Apricot is a deciduous crop belonging to family Rosacea. It is also grown in very low temperature $\left(-30{ }^{\circ} \mathrm{C}\right)$ areas having cold winters. In India, apricot is grown in Uttaranchal, Himachal Pradesh, and Jammu and Kashmir. In Jammu and Kashmir the estimated area of production for fresh apricot is 6123 hectares (DAR, 2017), and its production is confined to the lower belt of Ladakh region. Apricot kernels can be procured as a by-product from apricot processing plants. However, due to lack of efficient collection and utilization of kernel, this valuable crop remains unexploited. Apricot kernels have been used to extract oil from or as alternative protein source. Wild apricot kernel contains $40-56 \%$ of oil (MiAo et al., 2014), which is rich in essential fatty acids like oleic acid and linoleic acid, making it highly nutritious and a good source of unsaturated fatty acids. It is also helpful in the treatment of hypercholesterolemia (RAMADAN et al., 2011).

Extraction is one of the principal processing steps for isolation, identification, and purification of valuable compounds contained by plant based materials (STEVIGNY et al., 2007). Mass transfer and equilibrium phenomena determine the performance of extraction process. Also, the efficiency of extraction process depends upon many factors like temperature, solvent used, equipment, as well as the modes of operation. Screw press or continuous expeller are used for extraction of oilseeds, but it was impossible to extract the total oil content by these processes as the meal retained notable amount of oil inside the matrix. Ultrasound assisted extraction has been recognised as an efficient novel extraction technique that substantially reduces working time and increases the quality of the product (GAYAs et al.,

* To whom correspondence should be addressed.

E-mail: bazilagayass@gmail.com 
2016). The extraction of lipophilic ingredients from within the plant based material is significantly enhanced by using power ultrasound, where acoustic cavitation and mechanical effects result in enhancement of extraction efficiency. The mechanical effect of ultrasound assisted extraction facilitates the release of extractable components from the body of plant by distortion of cell walls, enhances mass transfer phenomenon, and eases access of solvent within the cell content (ZHANG et al., 2008). Ultrasound assisted extraction can be conducted at lower temperature, minimising thermal damage to the extract and loss of bioactive compounds (GAYAS et al., 2017).

In previous studies, conditions for ultrasound assisted extraction of apricot kernel oil were optimized and its effect on physical and chemical properties of extracted oil was studied (GAYAS et al., 2016). These results prompted us to extend our study to related techniques. The objective of the present study was to assess the physicochemical and morphological changes during ultrasound assisted extraction and its comparison with other extraction techniques viz. mechanical extraction (ME) and Soxhlet extraction (SE).

\section{Materials and methods}

\subsection{Materials}

Unshelled and dried apricot kernels were procured from Leh region of Jammu and Kashmir. The kernels were then ground by laboratory grinder.

\subsection{Methods}

1.2.1. Ultrasound assisted extraction. The ultrasound assisted extraction of apricot kernel powder was carried out in an ultrasonic cleaning bath at the frequency of $40 \mathrm{kHz}$ as per the method earlier described by GAYAS and co-workers (2016). Briefly, the samples prepared were placed in a conical flask of $250 \mathrm{ml}$, made up to the required volume with $\mathrm{n}$-hexane, and sonicated at optimum extraction parameters like solvent:sample ration 19.8:01; extraction temperature $51.72{ }^{\circ} \mathrm{C}$; and extraction time $43.95 \mathrm{~min}$.

1.2.2. Soxhlet extraction. The method described by BimakR and co-workers (2012) was employed for the extraction of oil by using $n$-hexane as solvent.

1.2.3. Mechanical extraction. The extraction process was carried out using a 'Mini oil mill'. The kernels were passed through the mill and the oil released drained into the base of the press, where it was collected. The meal obtained after the extraction was again passed through the expeller for extraction of the remaining oil. The oil expeller (Komet CA594, Germany) was a single screw type oil expeller driven by 1.5 HP motor.

\subsection{Analytical tests}

Determination of acid value, free fatty acid, specific gravity, saponification value, and iodine value of the extracted oil was carried out as per the standard AOAC (1980) methods. 


\subsection{Scanning electron microscopy (SEM)}

Hitachi S-3400N scanning electron microscope was used at an operating voltage of $15 \mathrm{kV}$. High resolution topographic images at low $(300 \times)$, medium $(500 \times)$, and high $(1000 \times)$ magnification were digitally recorded with short dwell times to prevent beam induced damage.

\subsection{Fourier Transform Infrared (FT-IR) spectra}

The FTIR spectrum of the oil samples was recorded by using FTIR spectrophotometer (ALPHA Bruker) with attenuated total reflectance (ATR) plate at $25 \pm 2{ }^{\circ} \mathrm{C}$. The spectra were recorded as $\%$ transmittance within the range of $600-4000 \mathrm{~cm}^{-1}$.

\subsection{Fatty acid composition}

Gas chromatography-mass spectrometry (GC-MS) analysis of FAME was performed with a Shimadzu QP2010 instrument (Shimadzu, Kyoto, Japan). An Rtx-5MS column (30 m $\times$ $0.25 \mathrm{~mm} \times 0.25 \mu \mathrm{m}$ ) was used. Oven temperature was raised from 184 to $191^{\circ} \mathrm{C}$ by a rate of $2{ }^{\circ} \mathrm{C} \mathrm{min}{ }^{-1}$. Injector and ion source temperature were set at 260 and $200{ }^{\circ} \mathrm{C}$, respectively. Helium was used as a carrier gas with a flow rate of $1.30 \mathrm{ml} \mathrm{min}^{-1}$ and a split ratio of 10:1. The identification of components based on NIST05.LIB and NIST05s.LIB with Shimadzu ChemStation software.

\section{Results and discussion}

\subsection{Physicochemical properties}

The physicochemical properties of apricot kernel oil extracted using different methods are shown in Table 1 . The oil contents of the kernel were significantly $(\mathrm{P}<0.05)$ different for the different extraction methods, and considerably higher yield was observed in UAE (44.72\%) and SE (44.33\%) as compared to $35.06 \%$ for ME. During ultra-sonication process the waves initiate the formation of cavities followed by their destruction. The small cavities growing with the expansion and compression cycle collapse after attaining a critical size, which in turn increases the contact area between kernels and solvent causing appearance of oil on the surface, easing the release of their content into the solvent medium, thus improving mass transfer (GAYAs et al., 2016).

The increased yield of oil from solvent extraction was attributed to longer extraction time $(6 \mathrm{~h})$ at high temperature, while UAE was performed in batch for $43.95 \mathrm{~min}$ at low temperature. Similar results were reported by PORTO and co-workers (2013) and DENT and co-workers (2015). Elevated temperature during SE caused superheating and degradation of heat-sensitive components. Mechanical extraction was found to be ineffective for oil extraction as the yield was relatively low and required re-extraction; similar results were also reported by SAMARAM and co-workers (2013). 
Table 1. Physico-chemical properties of apricot kernel oil obtained by different extraction methods

\begin{tabular}{lccc}
\hline Oil property & \multicolumn{3}{c}{ Extraction method } \\
\cline { 2 - 4 } & Mechanical & Soxhlet & Ultrasound assisted \\
\hline Oil yield (\%) & $35.06 \pm 0.03^{\mathrm{c}}$ & $44.33 \pm 0.26^{\mathrm{b}}$ & $44.72 \pm 0.06^{\mathrm{a}}$ \\
Acid value (mg KOH/g oil) & $2.71 \pm 0.01^{\mathrm{b}}$ & $2.86 \pm 0.03^{\mathrm{a}}$ & $2.73 \pm 0.01^{\mathrm{b}}$ \\
Free fatty acid (\%) & $1.36 \pm 0.01^{\mathrm{b}}$ & $1.44 \pm 0.01^{\mathrm{a}}$ & $1.37 \pm 0.01^{\mathrm{b}}$ \\
Saponification value $(\mathrm{mg} \mathrm{KOH} / \mathrm{g}$ oil) & $188.15 \pm 0.04^{\mathrm{c}}$ & $188.48 \pm 0.01^{\mathrm{a}}$ & $188.35 \pm 0.01^{\mathrm{b}}$ \\
Ester value $(\mathrm{mg} \mathrm{KOH} / \mathrm{g})$ & $185.44 \pm 0.04^{\mathrm{b}}$ & $185.61 \pm 0.03^{\mathrm{a}}$ & $185.62 \pm 0.02^{\mathrm{a}}$ \\
Specific gravity $\left(\mathrm{g} \mathrm{cm}{ }^{-3}\right)$ & $0.89 \pm 0.0^{\mathrm{a}}$ & $0.88 \pm 0.00^{\mathrm{b}}$ & $0.88 \pm 0.00^{\mathrm{b}}$ \\
Refractive index $\left(40^{\circ} \mathrm{C}\right)$ & $1.47 \pm 0^{\mathrm{a}}$ & $1.45 \pm 0.00^{\mathrm{c}}$ & $1.46 \pm 0.00^{\mathrm{b}}$ \\
Peroxide value $(\mathrm{meq} / \mathrm{kg}$ oil) & $5.03 \pm 0.02^{\mathrm{b}}$ & $5.09 \pm 0.01^{\mathrm{b}}$ & $5.17 \pm 0.05^{\mathrm{a}}$ \\
Iodine value $\left(\mathrm{gI}_{2} / 100 \mathrm{~g}\right.$ oil) & $98.97 \pm 0.06^{\mathrm{b}}$ & $99.49 \pm 0.01^{\mathrm{a}}$ & $99.00 \pm 0.02^{\mathrm{b}}$ \\
\hline
\end{tabular}

Values are reported as mean of triplicate \pm standard deviation

Means with different superscript differ significantly from each other row-wise at $\mathrm{P}<0.05$.

Acid value indicated the edibility of oil and its suitability to be used for industrial purpose, and in the present study the acid values fell within the recommended levels (virgin oil: 10 and non-virgin oil: 0.6) (DAwODU, 2009). However, higher acid value was observed in $\mathrm{SE}(2.866 \mathrm{mg} \mathrm{KOH} / \mathrm{g})$, which may be due to the depredating effect of longer extraction period. The saponification value of apricot kernel oil extracted by different methods varied significantly $(\mathrm{P}<0.05)$. High saponification value represents the commercial value of apricot kernel oil as it contains high molecular weight fatty acids and low level of impurities. The ester value of apricot kernel oil was found to be 185.4 , 185.6, and $185.6 \mathrm{mg} \mathrm{KOH} / \mathrm{g}$ for ME, SE, and UAE, respectively. Similar results were also reported by BACHHETI and co-workers (2012). The refractive index was almost similar for all extraction methods studied. It can be observed in Table 1 that the acid value, saponification value, and peroxide value are higher for SE extracted oil, which depicts that this method has deteriorating effect on the physicochemical properties of the oil.

\subsection{Morphological characteristics of kernel powder}

The scanning electron microscopy images of apricot kernel powder at a magnification factor of 1000 are shown in Figure 1. SEM was carried out to obtain more perception of the effect of ultrasound assisted extraction on apricot kernel powder. In order to increase the surface area of apricot kernel before extraction, grinding was carried out, which resulted in release of oil from the broken cells. Remarkable amounts of apricot kernel oil were evident on the SEM images taken before (Fig. 1A) and after (Fig. 1B-D) the extraction process. Fig. 1B shows that after mechanical extraction, the oil was still present in the sample compared to the other two extraction processes, where micro fractures in morphology due to ultrasonic cavitation appeared causing structural breakage. When comparing UAE with SE, more voids and cracks appeared in UAE treated apricot kernel powder than in apricot kernel powder with SE treatment. Similar patterns were observed in extraction of ginger oleoresin (SUPARDAN et al., 2011) and almond powder (ZHANG et al., 2009). 
A

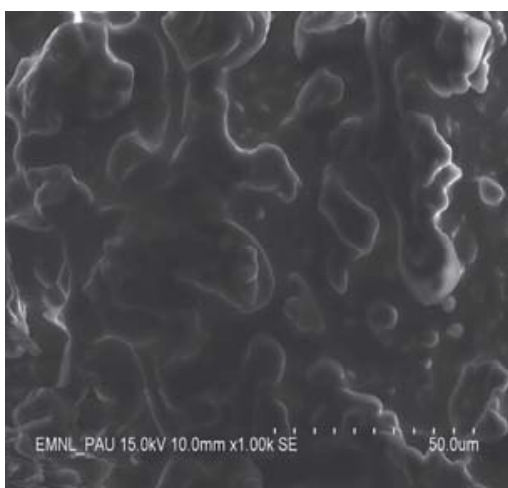

$\mathrm{C}$

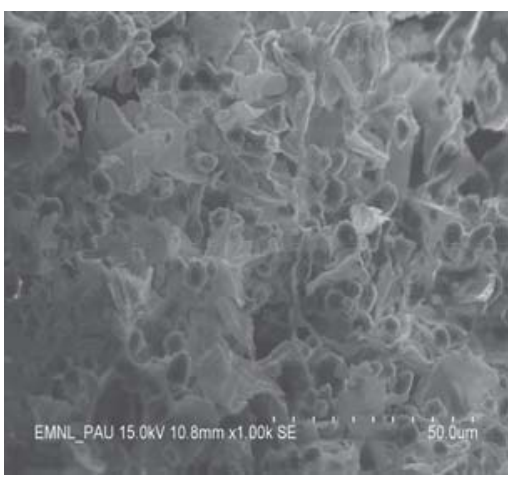

B

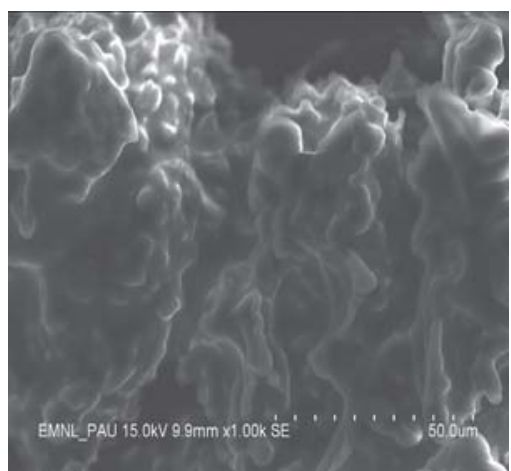

$\mathrm{D}$

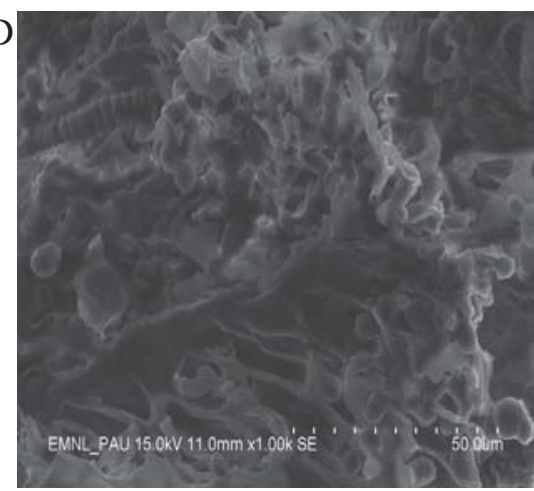

Fig. 1. Scanning electron microscopy images of apricot kernel powder.

A: untreated sample; B: mechanical extraction; C: Soxhlet extraction; D: ultrasound assisted extraction

\subsection{FT-IR spectroscopy}

Figure 2 shows the FT-IR spectra of apricot kernel oil extracted using ultrasound assisted extraction compared to conventional methods. Similar bands were noticed for all extraction methods used corresponding to specific functional groups. The results exhibit high reproducibility and show the existence of characteristic bands corresponding to saturated, monounsaturated, polyunsaturated fatty acids and glycerides. Two peaks at $2922 \mathrm{~cm}^{-1}$ and $2866 \mathrm{~cm}^{-1}$ were related to symmetrical and asymmetrical vibrations of aliphatic $\mathrm{C}-\mathrm{H}$ in $\mathrm{CH}_{2}$ and terminal $\mathrm{CH}_{3}$ functional groups, respectively (GARCIA-SALAS et al., 2013). The peak appearing at $1743 \mathrm{~cm}^{-1}$ is designated to the $\mathrm{C}=\mathrm{O}$ vibration of typical ester carbonyl group. Several peaks appeared in the peak range of $1466 \mathrm{~cm}^{-1}$ to $1233 \mathrm{~cm}^{-1}$ corresponding to the $\mathrm{CH}_{2}$ and $\mathrm{CH}_{3}$ group frequencies (HeRNANDEZ et al., 2009). The peaks at $1156 \mathrm{~cm}^{-1}$ and $1158 \mathrm{~cm}^{-1}$ are related to C-O-C group. The peaks at $717 \mathrm{~cm}^{-1}$ and $718 \mathrm{~cm}^{-1}$ represent aromatic compounds (Ali et al., 2015). 

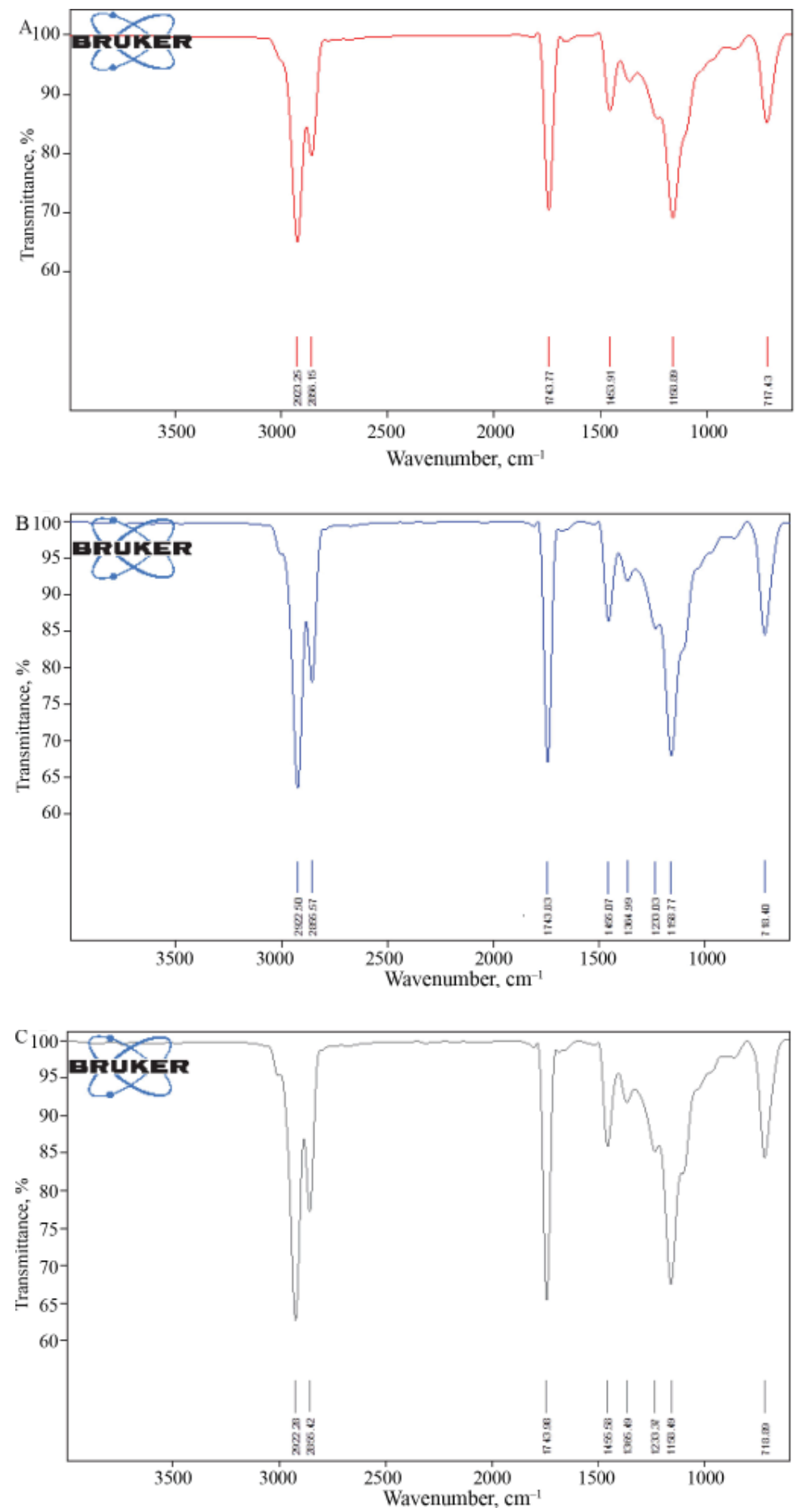

Fig. 2. FT-IR analysis of apricot kernel oils obtained by Soxhlet extraction (A), mechanical extraction (B), and ultrasound extraction $(\mathrm{C})$ 


\subsection{Fatty acid profile}

The fatty acid composition of apricot kernel oil extracted using different extraction methods is represented in Table 2 . There were no significant differences in fatty acid composition of the oils extracted by the three extraction techniques, which depicts that the oil composition was neither affected by the ultrasonic treatment nor by the mechanical or solvent extraction methods. The major fatty acid present in kernel oil was oleic acid, the amount of which stood out significantly $(\mathrm{P}<0.05)$ for all extraction methods. As per data given in Table 2, it can be observed that the oil extracted contains good amount of unsaturated fatty acids (linoleic acid and oleic acid) and relatively lower content of saturated fatty acids. Oleic acid is considered useful for the healthy diet as it helps to lower LDL cholesterol (GRUNDY, 1989). Linoleic acid, which is recognised as polyunsaturated fatty acid, is known to prevent the heart disease in humans (MANZOOR et al., 2007). The combination of high oleic and linoleic acid content in oil is of interest, as they are considered stable and nutritious oils that help prevent various diseases (RAMADAN et al., 2011). The fatty acid composition of aprioct kernel oil was found to be similar to the composition reported by DuBors and co-workers (2007) and TeNG and co-workers (2016) in various varieties of apricot kernel oil.

Table 2. Fatty acid composition of apricot kernel oil obtained by different extraction methods

\begin{tabular}{lccc}
\hline Fatty acid (\%) & \multicolumn{2}{c}{ Fatty acid extraction method } \\
& Mechanical & Soxhlet & Ultrasound assisted \\
\hline Palmitic acid (16:0) & $5.2 \pm 0.1^{\mathrm{a}}$ & $4.96 \pm 0.05^{\mathrm{b}}$ & $4.87 \pm 0.15^{\mathrm{b}}$ \\
Palmitoleic acid (16:1) & $0.66 \pm 0.05^{\mathrm{a}}$ & $0.51 \pm 0.02^{\mathrm{b}}$ & $0.52 \pm 0.05^{\mathrm{b}}$ \\
Stearic acid (18:0) & $1.28 \pm 0.02^{\mathrm{a}}$ & $0.97 \pm 0.03^{\mathrm{b}}$ & $0.85 \pm 0.03^{\mathrm{c}}$ \\
Oleic acid (18:1) & $67.45 \pm 0.04^{\mathrm{a}}$ & $66.87 \pm 0.01^{\mathrm{b}}$ & $66.85 \pm 0.04^{\mathrm{b}}$ \\
Linoleic acid (18:2) & $24.67 \pm 0.04^{\mathrm{c}}$ & $26.03 \pm 0.03^{\mathrm{b}}$ & $26.343 \pm 0.03^{\mathrm{a}}$ \\
Linolenic acid (18:3) & $0.71 \pm 0.03^{\mathrm{a}}$ & $0.67 \pm 0.04^{\mathrm{b}}$ & $0.73 \pm 0.03^{\mathrm{ab}}$ \\
\hline
\end{tabular}

Values are reported as mean of triplicate \pm standard deviation

Means with different superscript differ significantly from each other row-wise at $\mathrm{P}<0.05$.

Palmitic acid (C16:0) and stearic acid (C18:0) present in the kernel oil as saturated fatty acids range from $4.85-5.2 \%$ and $0.65-0.48 \%$, respectively. According to the results, amounts of palmitic acid and palmitoleic acid were not significantly $(\mathrm{P}<0.05)$ different for SE $(4.96 \%)$ and UAE (4.97\%) methods. These amounts are in agreement with the findings of studies on strawberry $(4.32 \%$ and $1.68 \%)$, red raspberry $(1.3-5.96 \%$ and $0.7-3.09 \%)$, and chokecherry (3.20\% and $1.57 \%$ ) seed oils (JoHANsson et al., 1997).

\section{Conclusions}

The present research assessed the practicability of ultrasound assisted extraction for recovery of oil from apricot kernel and its comparison with conventional extraction methods viz. mechanical and Soxhlet extraction. Compared with the mechanical extraction, much higher 
yield was obtained using ultrasound assisted extraction, which was also depicted through SEM images showing more voids and cracks in UAE treated powder. The different methods of extraction exert a significant influence on the fatty acid composition in the oil. FT-IR spectra show that extraction method exerts less profound effect on functional groups of extracted kernel oil. The oil extracted through UAE exhibits higher oil yield, higher acid and peroxide values in comparison to oil extracted by conventional methods.

The author thanks the Electron Microscopy and Nanotechnology Lab of PAU, Ludhiana for providing the laboratory facilities. Author also acknowledges UGC, GOI, for providing Maulana Azad National Fellowship.

\section{References}

Ali, M.A., Al-Hattab, T.A. \& Al-Hydary, I.A. (2015): Extraction of date palm seed oil (Phoenix dactylifera) by Soxhlet apparatus. IJAET, 8, 261-271.

AOAC (1980): Official methods of analysis of the Association of Official Analytical Chemists. $13^{\text {th }}$ ed. Washington, DC. Methods no. 920.160, 920.212, 940.28, 993.20.

Bachieti, R.K., RaI, I., Joshi, A. \& Rana. V. (2010): Physico-chemical study of seed oil of Prunus armeniaca L. grown in Garhwal region (India) and its comparison with some conventional food oils. Int. Food Res. J., 19, $577-581$.

Bimakr, M., Rahman, A., Taip, F.S., Adzahan, N.M., Sarker, M.Z.I. \& Ganjloo, A. (2012): Optimization of ultrasound assisted extraction of crude oil from winter melon (Benincasa hispida) seed using response surface methodology and evaluation of its antioxidant activity, total phenolic content and fatty acid composition. Molecules, 17, 11748-11762.

DAR, F.A. (2017): Production of fresh and dry fruits, a district wise analysis in Jammu and Kashmir. Int. J. App. Res. (IJAR), 3, 336-340.

Dawodu, F.A. (2009): Physico-chemical studies on oil extraction processes from some Nigerian grown plant seeds. EJEAFChe., 8, 102-110.

Dent, M., Dragovic-Uzelac, V., Garofulic, I.E., Bosiljkov, T., Jezek, D. \& Brncic, M. (2015): Comparison of conventional and ultrasound assisted extraction techniques on mass fraction of phenolic compounds from sage (Salvia officinalis L.). Chem. Biochem. Eng. Q., 29, 475-484.

Dubois, V., Breton, S., Linder, M., Fanni, J. \& Parmentier, M. (2007): Fatty acid profiles of 80 vegetable oils with regard to their nutritional potential. Eur. J. Lipid Sci. Tech., 109, 710-732.

Garcia-Salas, P., Gomez-Caravaca, A.M., Arraez-Roman, D., Segura-Carretero, A., Guerra- Harnandez, E., ... \& FernandeZ-Gutierrez, A. (2013): Influence of technological processes on phenolic compounds, organic acids, furanic derivatives, and antioxidant activity of whole-lemon powder. Food Chem., 141, 869878.

GaYAS, B. \& KauR, G. (2017): Novel oil extraction methods in food industry: A review. J. Oilseed Brass., 8, 1-11.

GAYAS, B., KAUR, G. \& GUL, K. (2016): Ultrasound assisted extraction of apricot kernel oil: Effects on functional and rheological properties. J. Food Process Eng., 40(3), e12439.

GrundY, S.M. (1989): Monounsaturated fatty acids and cholesterol metabolism implications for dietary recommendations. J. Nutr., 119, 529-533.

HernandeZ, Y., LoBo, G. \& GonZALEZ, M. (2009): Factors affecting sample extraction in the liquid chromatographic determination of organic acids in papaya and pineapple. Food Chem., 114734-114741.

Johansson, M.M., Swan, D.D., Surette, M.E., Stenger, J., Chilton, T., ... \& \& Chilton, F.N. (1997): Dietary supplementation with gamma-linolenic acid alters fatty acid content and eicosanoid production in healthy humans. J. Nutr., 127, 1435-1444.

Manzoor, M., Anwar, F., Iqbal, T. \& Bhnager, M.I. (2007): Physico-chemical characterization of Moringa concanensis seeds and seed oil. J. Am. Oil Chem. Soc., 84, 413-419.

Miao, X., ZhoA, Z., Li, H. \& Li, M. (2014): Acute toxicity of refined wild apricot oil in rats. ScienceAsia., 40, $323-326$. 
Porto, D.A., Porretto, E. \& DeCorti, D. (2013): Comparison of ultrasound assisted extraction with conventional extraction methods of oil and polyphenols from grape (Vitis vinifera L.) seeds. Ultrason. Sonochem., 20, 1076-1080.

Ramadan, M.F., ZAYed, R., Abozid, M. \& Asker, M.M S. (2011): Apricot and pumpkin oils reduce plasma cholesterol and triacylglycerol concentrations in rats fed a high-fat diet. Grasas Aceites, 62, 443-451.

Samaram, S., Mirhosseini, H., Tan, C.G. \& Ghazali, H.M. (2013): Ultrasound assisted extraction (UAE) and solvent extraction of papaya seed oil: yield, fatty acid composition and triacylglycerol profile. Molecules, 18 , $12474-12487$.

Stevigny, C., Rolle, L., Valentini, N. \& Zeppa, G. (2007): Optimization of extraction of phenolic content from hazelnut shell using response surface methodology. J. Sci. Food Agr., 87, 2817-2822.

Supardan, M.D., FuAdi, A., Alam, P.N. \& ArPI, N. (2011): Solvent extraction of ginger oleoresin using ultrasound. Makara J. Sci., 15, 163-167.

Teng, H., Chen, L., Huang, Q., Wang, J., Lin, Q., .. \& Song, H. (2016): Ultrasonic assisted extraction of raspberry seed oil and evaluation of its physico-chemical properties, fatty acid compositions and antioxidant activities. PLoS One. 11, e0153457.

Zhang, Z.S., WANG, L.J., Li, D., JiAo, S.S., Chen, X.D. \& MaO, Z.H. (2008): Ultrasound assisted extraction of oil from flaxseed. Sep. Purif. Technol., 62, 192-198.

Zhang, Q., Zhang, Z., Yue, X., Fan, X., LI, T. \& Chen, S. (2009): Response surface optimization of ultrasoundassisted oil extraction from autoclaved almond powder. Food Chem., 116, 513-518. 